\title{
COALITION GOVERNMENTS AND SOVEREIGN DEBT CRISES
}

\author{
Sebastian M. SAIEGH*
}

\begin{abstract}
This article examines the domestic politics of sovereign debt crises. I focus on two alternative mechanisms that aggregate the preferences of domestic actors over debt repayment: single-party versus multiparty coalition governments. I uncover a very strong empirical regularity using cross-national data from 48 developing countries between 1971 and 1997. Countries that are governed by a coalition of parties are less likely to reschedule their debts than those under single-party governments. The effect of multiparty coalitions on sovereign defaults is quantitatively large and roughly of the same order of magnitude as liquidity factors such as debt burden and debt service. These results are robust to numerous specifications and samples.
\end{abstract}

\section{INTRODUCTION}

DEFAULTS BY sovereign governments on bonds and bank loans have historically reflected a variety of factors such as wars, revolutions, lax fiscal and monetary policies, and external economic shocks. More recently, fiscal discipline and debt management pose significant challenges for many countries. Beginning in the late 1970s, the proportion of governments with debt in default rose sharply and peaked at $29.6 \%$ in 1990 . The total value of sovereign bonds and bank loans in default also reached its peak in 1990 (US $\$ 335$ billion). Recent defaulters include Russia (1998-2000), Ecuador (1999-2000), Pakistan (1999), and Argentina (2001-2005).

The Argentine default can be viewed as the culmination of a series of political events that occurred in previous years. In the presidential campaign of 1999, debt repayment took center stage and the two leading contenders adopted opposing positions on the issue. The Peronist party candidate, Eduardo Duhalde, argued that debt payments were "bleeding" the country and stated that "with current levels of debt servicing there would be no possible recovery" for Argentina. He then called on foreign creditors to cancel the debt. ${ }^{1}$ However, the candidate of the multiparty coalition (Alianza), Fernando de la Rua, maintained that the country should uphold its commitments, even if it meant austerity at home (Tomz, 2002).

\footnotetext{
*Corresponding author: Sebastian M. Saiegh, Department of Political Science, University of California San Diego, 9500 Gilman Drive, La Jolla, CA 92093, USA. E-mail: ssaiegh@ucsd.edu

${ }^{1}$ Duhalde's quote comes from Tomz (2002).
} 
The Alianza won the 1999 election with a plurality of the vote. Nonetheless, the coalition government almost dissolved a year later when the leader of one of the parties in the coalition government announced his resignation from the Vice-Presidency. The fate of de la Rua's presidency was definitively sealed on the night of October 14, 2001. After almost two years in power, his administration lost control of Congress to the Peronist party. The legislative elections have been characterized as a referendum on the austerity needed to meet IMF targets and remain current with creditors (see Tomz, 2003). The de la Rua administration implemented a series of budget cuts required for debt repayment, including the "zero-deficit" plan and a reduction in salaries for public sector employees. But, as the elections approached, even members of de la Rua's party decided to break with him over the issue of debt repayment. Meanwhile, the Peronist party candidates openly campaigned using a pro-default rhetoric. The election outcome was clearly a victory for those who did not want to repay the sovereign debt (Tomz, 2002, 2003).

Without popular support, increasingly isolated within its own coalition and lacking majority backing in the legislature, de la Rua left office on December 19, 2001. Although the macroeconomic conditions had not changed following his resignation, the new authorities rushed to declare a moratorium. On December 24, Adolfo Rodriguez Saa was appointed as interim president and officially announced his plan to halt payment on government debt. His successor, Eduardo Duhalde, closed the circle and on January 3, 2002, defaulted on a US\$28 million interest payment due on an Italian lira bond.

The Argentine example leads to the following question: Why do some governments default on their sovereign debts while others do not? The classic literature on sovereign debt identifies a "willingness to pay" as the main factor that distinguishes sovereign debt from ordinary debt owed by non-government entities. In the corporate world, debt contracts are enforced by the threat of liquidation in the event of default. In contrast, creditors have limited legal redress in the case of sovereign entities. Therefore, governments can (and sometimes do) default selectively on their obligations, even when they possess the financial capacity for timely debt service.

Most economists acknowledge that political constraints shape a country's willingness to adopt unpopular measures. However, little systematic work studies the role of domestic politics on debtor-creditor relations. And, while the international political economy literature often recognizes that a policy assumed to be in the interest of a debtor country is not necessarily in the interest of everyone in that country, the specific mechanisms through which different preferences over policy are aggregated are seldom discussed. This paper fills this gap in the literature. I focus on two alternative mechanisms that aggregate the preferences of domestic actors, single-party versus multiparty coalitions, to examine the politics of debt repudiation in the developing world. 
Using cross-national data from 1971 to 1997 in 48 developing countries, I identify a very strong empirical regularity: the probability of debt repudiation is lower when there is a multiparty coalition rather than a singleparty government in power. This main result is robust to extensive controls and to numerous changes of specifications and samples. Beyond providing a contribution to the existing literature on the political economy of debt, this finding has important implications for both scholars and policy-makers who analyze sovereign borrowing. Specifically, it highlights the inappropriateness of the strategies used by official multilateral lenders. These agencies rarely focus on domestic politics to predict a country's debt sustainability and, instead, rely almost exclusively on debt burden indicators to make those predictions.

This paper builds on the literature on sovereign debt crises dating back to the classical work of Bulow and Rogoff (1989) and Edwards (1984). ${ }^{2}$ I depart from this work by emphasizing the role of domestic politics in debt repayment. In this regard, this paper is closely related to and complements the work of Stasavage (2003). He considers a setting in which rulers can either service the public debt by cutting expenditures/raising taxes, or can stop making payments on their obligations and use the revenue to maintain their levels of public spending. As he notes, when governments make decisions like these, they almost certainly need to account for those in society who own public debt and those who pay the taxes to service the public debt. For those who own public debt, the government's decision will have a direct impact on their welfare. These individuals clearly have an incentive to demand from the government that sovereign debt be honored. The government decision would also have an impact on those who contribute to repay debts, as it would affect their burden of taxation (Stasavage, 2003). In fact, if the decision to default is motivated by the government's desire to finance its public expenditures at current levels, then every member of society will have induced preferences over debt repayment irrespective of whether he/she is actually a government creditor or not. As a result, a large group in the population may regard debt repudiation as the best way to promote its own welfare. However, even if those who defend debt repayment are a small minority, they may still be able to gain the support of other groups on noneconomic issues such as religious tolerance, foreign policy, or constitutional questions. Therefore, cross-issue coalitions can reduce the risk of default (Stasavage, 2003). ${ }^{3}$

Other studies have also explored how the government's partisan composition affects policy decisions. Bawn and Rosenbluth (2006) contend that when governments rely on a single-party majority, the main competition for

\footnotetext{
${ }^{2}$ For an excellent survey of this literature, see Eaton and Fernandez (1995).

${ }^{3}$ Dixit and Londregan (1998) suggest that when politically powerful groups invest in government debt, then the repayment promise is more credible.
} 
votes is between the incumbent and the opposition; and that this dynamic pushes the incumbent toward policies that only benefit the voters represented in office. But, if the government is supported by a coalition of parties, voters can distinguish between the parties in office, creating opportunities for cross-issue deals inside the governing coalition (Bawn and Rosenbluth, 2006). More importantly, multiparty coalition governments can also provide guarantees for those with a stake in debt repayment because, regardless of their electoral size, coalition partners can potentially "make or break" governments. Kohlscheen (2006) finds that the confidence vote requirement makes default a less likely equilibrium outcome in parliamentary democracies. ${ }^{4}$ Relatedly, Tsebelis (2002) demonstrates that the existence of a large number of veto players helps "lock in" economic policy. As coalition governments have more players who could potentially veto a change, they could uphold such a policy, and thus maintain debt service in the face of adverse shocks.

Finally, the paper's main result is related to the empirical work that focuses on the effects of political institutions on sovereign debt default. For example, Kraay and Nehru (2006) find a negative relationship between measures of the quality of policies and institutions (the World Bank's CPIA index) and the incidence of "debt distress" episodes. Kohlscheen (2006) and Van Rijckeghem and Weder (2004) show that the probability of debt rescheduling is lower in parliamentary democracies than in non-parliamentary regimes. Both studies also examine default propensities conditional on whether or not government parties hold a majority of seats in the legislature and whether the majority status is achieved alone or through the formation of a multiparty coalition. However, these studies do not examine the government's coalition status directly. Instead, they use an aggregate index of political constraints developed by Henisz (2000). Kohlscheen (2006) considers the effect of coalition governments on debt rescheduling, but restricts his attention to parliamentary democracies. This is problematic because government coalitions are less frequent, but not exceptional under presidentialism. In fact, Cheibub et al. (2004) calculate the number of cabinets that include members of opposition parties to be one of every four under presidentialism, or more than half excluding majority presidents. Therefore, this is the first paper to directly estimate the effect of government coalitions on debt rescheduling under both presidentialism and parliamentarism.

The reminder of this article is organized as follows. The next section describes the data used in this study and the main empirical results. In the third section, a series of robustness checks are presented. A final section concludes.

\footnotetext{
${ }^{4} \mathrm{His}$ results also consider the case of multiple veto players checking the executive, but exclude cases of government coalitions under presidentialism.
} 


\section{DATA AND ESTIMATION}

The existing literature suggests that partisan compromises can reduce default risk, but they will be unable to do so unless creditor interests possess power within a representative government, either as an outright majority or as a part of a government coalition. The group of individuals who have an incentive to demand from the government that sovereign debt be honored is often reduced to a small segment of the population in less developed countries. Therefore, the main observable implication is that in these countries, the probability of debt repudiation should be lower under a multiparty coalition than in a single-party government.

\subsection{The Data}

To evaluate the effect of domestic politics on sovereign default in less developed countries, I use an original dataset that draws on and updates the Cheibub et al. (2004) coalition governments dataset, the Golder (2005) dataset on electoral systems, and data on sovereign debt default collected by the World Bank. As such, this dataset includes information about the coalitional structure of governments and data on debt rescheduling. The data also include information on the electoral settings under which these coalitions form.

My baseline dependent variable measures whether a debt-rescheduling situation occurs in a given year. I define default as an event when the scheduled debt service is not paid on the due date or the sovereign makes a restructuring offer that contains terms less favorable than the original debt, as opposed to an outright repudiation of debts or a unilateral suspension of payments. This conceptualization is consistent with the technical definition applied by credit-rating agencies (Beers and Chambers, 2006; InterAmerican Development Bank, 2007) and with existing empirical studies (Kohlscheen, 2006; Kraay and Nehru, 2006; Tomz and Wright, 2007; Van Rijckeghem and Weder, 2006). Thus, my Debt Restructuring variable is defined broadly to include rescheduling or restructuring of debt, including arrears on either principal or interests. ${ }^{5}$ It is a binary indicator that takes the value of 1 if such events are observed and 0 otherwise. ${ }^{6}$

The main independent variables of interest are government type and electoral rules. With respect to the former, Cheibub et al. (2004) consider a government to be a multiparty coalition when two or more political parties represented in the national legislature hold cabinet positions. ${ }^{7}$ Hence,

\footnotetext{
${ }^{5}$ Alternatively, a more stringent definition of debt rescheduling - one that excludes arrears on either principal or interests - can be adopted. I discuss this possibility and its effect on the estimation results below (Table 4).

${ }^{6}$ The variable was constructed with data in the World Bank's Global Development Finance Report (1999).

${ }^{7}$ These portfolio coalitions are different from legislative or policy coalitions. If parties are disciplined, then every government coalition is a legislative coalition. Legislative coalitions, in turn, may vary from one issue to another. Such variations may arise from the fact that parties
} 
Government Coalition is a binary indicator that takes the value of 1 if the government is a multiparty coalition, and 0 otherwise. Unlike previous studies (Henisz, 2000; Van Rijckeghem and Weder, 2004), this indicator enables me to conduct a direct test of the relationship between government coalitions and debt rescheduling.

I also use two alternative measures to examine how the government's partisan composition affects policy decisions. ${ }^{8}$ The first measure, Parties in Government, is the natural logarithm of the number of parties included in the government. This indicator takes a non-negative value greater than 0 if the government is a multiparty coalition, and 0 otherwise [i.e. $\ln (1)=0]$.

In many situations, however, the parties represented in the government may vary substantially in their seat shares. With this in mind, I use the Herfindahl-Hirschman ( $\mathrm{HH})$ index of concentration as my measure of a government's partisan concentration. Hence, Concentration is computed as

$$
H H=\sum_{i} p_{i}^{2}
$$

where $p_{i}=s_{i} / S, s_{i}$ is the number of seats of party $i$, and $S$ is the total number of seats held by the government. This indicator reaches its maximum value 1 under single-party governments $\left(p_{k}=1\right.$ for one party $k$ and $p_{i}=0$ for all others). The minimum 0 is approached when all parties included in the government have equal numbers of seats and the number of parties increases (Theil, 1972). It is also worth noting that the HH index of concentration is the denominator of the well-known Laakso-Taagepera (LT) index, which is commonly used to gauge the "effective" number of political parties (Laakso and Taagepera, 1979). Thus, the LT index is the inverse of the HH index. As such, in contrast to the previous two measures, in this case we should expect to observe a positive correlation between the concentration index and sovereign debt rescheduling.

To properly evaluate how the government's partisan composition affects the politics of debt repayment, it is necessary to account for the confounding effects of electoral rules. A long tradition in comparative politics stresses the relationship between electoral rules and types of government. For instance, plurality rule and small district magnitude are associated with fewer parties than are proportional representation and a large district magnitude. Moreover, in parliamentary democracies, fewer parties are

may vote together on some but not all issues or from lack of party discipline among members. Amorim Neto (2000) claims that, as distinct from parliamentarism, under presidentialism participation in a portfolio government does not bind legislators to support the president. Yet even if party discipline were to be lower under presidentialism - something about which I am agnostic - the effect on presidential coalitions would be indeterminate: it would depend on which parties, government or opposition, are less disciplined.

${ }^{8}$ The data used to construct these measures were obtained from Cheibub et al. (2004). 
frequently associated with more single-party majority governments, and fewer coalition governments. The characteristics of the party system induced by the electoral rules can also lead to systematic differences in economic policy-making. ${ }^{9}$

Iversen and Soskice (2006) provide a sophisticated argument linking electoral rules and economic policies. They find that in the OECD countries, proportional representation is frequently associated with center-left coalition governments, while single-party right-wing governments are more frequent under majoritarian elections. This contention has two important implications for the empirical test proposed in this paper. First, the correlation between the electoral rules and the government's ideology, rather than the prevalence of coalitions, could explain why proportional representation systems adopt certain types of policies. Second, based on Iverson and Soskice's contentions, the net effect of the electoral formula on default should be indeterminate. While proportional representation should be associated with lower default probabilities (i.e. if the multiparty coalition effect dominates), it should also be associated with center-left governments. Therefore, in such systems we should expect governments to default more often.

Two additional caveats are worth mentioning. First, Iversen and Soskice assume that under proportional representation, when no party has a majority, governments must be based on a coalition of parties. ${ }^{10}$ This is not the case in the countries that I examine in this paper. Many presidents in Latin America are elected under proportional representation but form single-party minority governments. Furthermore, the correlation between proportional representation systems and center-left governments found by Iversen and Soskice is restricted to OECD countries. ${ }^{11}$ Second, recent studies suggest that the government's ideological makeup fails to have predictable effects on the implemented policies in the developing world. In fact, a few studies demonstrate that the effect of ideology is often at odds with cursory expectations. Leblang (2003) finds that right-wing governments are less likely to defend their exchange rate than they are to devalue after suffering a speculative currency attack. Similarly, Pinto (2005) provides compelling evidence that FDI regimes are more likely to be friendly to foreign capital under pro-labor than under pro-business governments. Therefore, I am agnostic about the relationship between coalition status and ideology.

\footnotetext{
${ }^{9}$ According to Myerson (1993), plurality voting rules tend to favor minority groups. AustenSmith (2000) argues that proportional representation is associated with higher redistributive taxes than are two-party majoritarian systems. Lizzeri and Persico (2001) argue that majoritarian systems generate less public-good provision than proportional systems. Lastly, Persson et al. (2003) find that proportional representation leads to more government spending than plurality rule.

${ }^{10}$ The results by Persson et al. (2003) also cast some doubt on the arguments advanced by Iversen and Soskice.

${ }^{11} \mathrm{I}$ am not aware of any study that would confirm or disconfirm this finding in the developing world.
} 
My indicator for the electoral rules, Proportional Representation, takes the value of 1 if the electoral system in place employs proportional formulas, and 0 otherwise (i.e. majoritarian, multitier, or mixed type). These formulas include both quota systems (Hare, Droop, Imperiali, and Reinforced Imperiali), and highest average systems (d'Hondt series, Sainte-Laguë series, and Modified Sainte-Laguë series). ${ }^{12}$

As discussed in the introduction, countries may be unwilling to repay their debt, based on a consideration of the relative costs and benefits of default. On the other hand, countries may be unable to repay their debt because they are either insolvent or illiquid. The literature suggests a number of macroeconomic factors that influence the likelihood of sovereign debt servicing difficulties and default. ${ }^{13}$ Therefore, the core specifications include the following explanatory variables: ${ }^{14}$

1. Debt/output ratio: In most models of sovereign borrowing, the level of debt plays a crucial role: whether a country is solvent or not depends on its stock of debt relative to its ability to pay (Edwards, 1984; Sachs, 1984). This variable captures the degree of solvency of a particular country. Therefore, ceteris paribus, it is expected that it will have a positive sign (Min et al., 2003; Sachs and Cohen, 1982).

2. Debt/service ratio: This indicator, computed as the ratio of debt service to exports, measures possible liquidity (as opposed to solvency) problems faced by a particular country (Edwards, 1984). A debt crisis can also occur if a country is illiquid rather than insolvent (Roubini and Manasse, 2005). Given the adverse effect of higher debt service ratios on a country's ability to repay its debt, I expect its coefficient to have a positive sign.

3. The ratio of the current account to gross national product (GNP): Current account imbalances may also affect a country's ability to repay, for any given level of existing debt. The higher the current account balance-to-GNP ratio, the smaller will be the possibility of a liquidity crisis (Sachs, 1981). In addition, this indicator measures the quantity of investment financed through borrowing from abroad. As such, it should capture a country's perspectives for future growth and therefore be negatively related to rescheduling probabilities (Cohen and Sachs, 1986; Edwards, 1984).

\footnotetext{
${ }^{12}$ The data were obtained from Golder (2005).

${ }^{13}$ It is worth mentioning that no "canonical" model exists in the literature (Palac-McMilken, 1995; Roubini and Manasse, 2005). I estimated a number of different models including variables suggested by existing studies. A summary of the results from the different models is available on request. The model used here is based on Edwards (1984), who looks specifically at developing countries' foreign borrowing and default risk.

${ }^{14}$ The data were obtained from the World Bank Global Development Finance Report (1999) and the World Bank Development Report (1999).
} 
4. The ratio of international reserves to total debt: This variable measures the level of international liquidity held by a country. In contrast to the previous variable, the lower the international reserves to debt ratio, the greater there will be a threat of a sudden liquidity crisis, and so it is expected that the coefficient on this variable will be negative (Edwards, 1984; Min et al., 2003; however, Gersovitz, 1985, claimed that the sign would be positive).

5. Change in GNP (growth): It has been argued that a decline in the growth rate of output can contribute to a long-term insolvency problem leading to higher default probabilities (Feder and Just, 1977). On the other hand, a decline in growth may ameliorate an external liquidity constraint through lower imports and can lead to a lower probability of a debt crisis; therefore, the impact of this variable on default is uncertain (Min et al., 2003).

6. The ratio of short-term debt to total debt: The link between short-term debt and crises has been rationalized through models of sovereign debt rollover (Jeanne, 2004; Rodrik and Velasco, 1999). In these models, a sovereign debtor needs to service a large amount of obligations coming due. If creditors do not roll over some or all of the maturing debt, default is the optimal choice, while if the loan is rolled over the debtor country is better off repaying (Detragiache and Spilimbergo, 2001). This variable thus captures the fact that many countries are able to avoid a rescheduling of their sovereign debt by borrowing short-term funds in the international markets. It should be negatively correlated to rescheduling probability.

7. Sum of past reschedulings: As suggested by the "debt intolerance" hypothesis (Reinhart et al., 2003), a "history" of past defaults may bear on the credibility of a sovereign and thus affect the default probability. This variable measures how countries' rescheduling probabilities are affected by their past behavior. In particular, I expect the coefficient on this variable to be positive.

\subsection{Variation in Debt Rescheduling across Government Types}

The sample consists of 502 observations on 48 countries for the 1971-1997 period. It includes 324 debt-rescheduling cases that cover 43 countries. The choice of these countries is dictated by data availability. Appendix A provides a list of countries included in the sample. ${ }^{15}$ Table 1 provides the descriptive statistics for the country-year observations, classified by their type of government. These figures demonstrate that multiparty coalition governments reschedule their debts less often than single-party governments.

\footnotetext{
${ }^{15}$ The coverage depends on the World Bank's classification of LDCs. This is why, for example, Malta - a European country - is included in the sample.
} 
Table 1 Descriptive Statistics for Country-Year Observations Means (Standard Deviations in Parentheses)

\begin{tabular}{lccc}
\hline & All & Multiparty coalition & Single-party \\
\hline Default (including arrears) & 0.64 & $0.56^{\mathrm{a}}$ & $0.71^{\mathrm{a}}$ \\
& $(0.48)$ & $(0.50)$ & $(0.45)$ \\
Default (excluding arrears) & 0.31 & 0.27 & 0.33 \\
& $(0.46)$ & $(0.45)$ & $(0.47)$ \\
Proportional Representation & 0.39 & 0.37 & 0.42 \\
& $(0.49)$ & $(0.48)$ & $(0.49)$ \\
Debt/Output & 61.44 & 50.56 & 70.29 \\
& $(96.62)$ & $(27.94)$ & $(127.03)$ \\
Debt/Service Payments & 221.04 & 189.96 & 246.28 \\
& $(307.49)$ & $(120.54)$ & $(398.01)$ \\
Current Account/GNP & -0.03 & -0.03 & -0.03 \\
& $(0.07)$ & $(0.05)$ & $(0.08)$ \\
Reserves/Total Debt & 72.72 & 31.53 & 106.18 \\
& $(212.96)$ & $(29.71)$ & 0.05 \\
Growth & 0.05 & 0.06 & $(0.18)$ \\
& $(0.16)$ & $(0.13)$ & 18.49 \\
Short-Term/Total Debt & 17.44 & 16.13 & $(17.18)$ \\
& $(15.08)$ & $(11.89)$ & 7.33 \\
Past Reschedulings & 7.62 & 7.97 & $(5.87)$ \\
& $(6.68)$ & $(7.56)$ & 277 \\
N & 502 & 225 & \\
\hline
\end{tabular}

Notes: ${ }^{a}$ I use a $t$-test to examine differences in average debt rescheduling under multiparty coalitions and single-party governments. Bartlett's $\chi^{2}$-statistic $(0.134)$ does not reject the null hypothesis of equal variance. Therefore, the $t$-test is valid $(t=3.654$ and $p<0.0001)$. The $t$-statistic and its $p$-value reject the null hypothesis that the difference in means is zero.

The unconditional probability of a multiparty coalition government rescheduling its sovereign debt in any given year during the period was $56 \%$, compared with $71 \%$ for single-party governments. ${ }^{16}$

The observed differences across these types of governments with respect to their solvency and liquidity can be attributed to outlying observations from two countries in the sample (Nicaragua 1990-1996 and Malta 1971-1987). No significant differences exist between multiparty coalitions and singleparty governments in the solvency and liquidity indicators when I exclude these observations. ${ }^{17}$ Contrary to what occurs in OECD countries, proportional representation systems in the developing world are not necessarily associated with multiparty coalition governments (the two variables are correlated at 0.15 ).

\footnotetext{
${ }^{16} \mathrm{~A}$ comparison of means test allows us to reject the hypothesis that the average rescheduling for multiparty coalitions and single-party governments are equal. Bartlett's $\chi^{2}$-statistic $(0.134)$ does not reject the null hypothesis of equal variance. Therefore, the $t$-test is valid $(t=3.654$ and $p<0.0001)$.

${ }^{17}$ None of the results presented below are sensitive to these two cases.
} 
Next, I present my statistical results. The following probit specification is used to model the probability of default:

$$
P\left[y_{c t}=1\right]=\Phi\left(\beta^{\prime} \mathbf{X}_{c t}\right),
$$

where $y_{c t}$ is my indicator of rescheduling episodes, each corresponding to country $c$ at time $t ; \Phi(\cdot)$ denotes the normal distribution function; $\mathbf{X}_{c t}$ denotes a vector of determinants of default; and $\beta$ is a vector of parameters to be estimated. ${ }^{18}$

Table 2 reports the core specifications. The second column presents the results of the model that excludes the government coalition variable. The third and fourth columns report the models including the type of government and electoral rules among the independent variables. The last two columns present the results of the models including the alternative measures of the government's partisan composition.

These estimates lend considerable support to the notion that in the developing world, multiparty coalition governments are less likely to reschedule their debts than are single-party governments. When the government status is measured using the logarithm of the number of government parties, the results are almost identical. Likewise, the higher the government's partisan concentration, the greater is the probability of a debt crisis.

To gain a more substantive understanding of this relationship, I calculate marginal effects based on the estimates reported in column 4. They are calculated as the change in the probability of debt rescheduling given a country's coalition status, while keeping all the other independent variables at their means. Having a multiparty coalition government diminishes the probability of debt rescheduling by $19 \%$. To place this percentage in context, recall that the difference in the unconditional probability of default between single-party and multiparty coalition governments in my sample is $15 \%$.

My results also corroborate the effect of coalition governments after controlling for economic variables used in previous studies as well as electoral rules. Moreover, they suggest that proportional representation polities default more often than majoritarian systems, which is consistent with the empirical results in Austen-Smith (2000). ${ }^{19}$

The estimated coefficients for the economic variables are in line with the expectations laid out above. The coefficient for the debt-output ratio is positive and statistically significant, indicating that a higher level of indebtedness is associated with a higher probability of debt rescheduling. With

\footnotetext{
${ }^{18}$ This simple probit specification is adequate because my interest here is the incidence of rescheduling episodes rather than their precise timing. See Kraay and Nehru (2006) for a similar treatment.

${ }^{19} \mathrm{I}$ also estimated the model taking into account separation of powers. As an additional robustness check, I recoded the variable Proportional Representation to include multitier and mixed systems. This modification had no effects on the results.
} 
Table 2 Binary Probit Estimates of Debt Rescheduling

\begin{tabular}{|c|c|c|c|c|c|}
\hline & $\begin{array}{l}\text { Initial } \\
\text { model }\end{array}$ & $\begin{array}{l}\text { Government } \\
\text { Coalition }\end{array}$ & $\begin{array}{l}\text { Electoral } \\
\text { Rules }\end{array}$ & $\begin{array}{l}\text { Government } \\
\text { Parties (ln) }\end{array}$ & $\begin{array}{c}\text { Concentration } \\
\text { index }\end{array}$ \\
\hline Constant & $\begin{array}{l}-1.140^{* * *} \\
(0.249)\end{array}$ & $\begin{array}{l}-0.724^{* * * *} \\
(0.272)\end{array}$ & $\begin{array}{l}-0.732^{* * *} \\
(0.276)\end{array}$ & $\begin{array}{r}-0.718^{*} \\
(0.278)\end{array}$ & $\begin{array}{c}-2.319^{* * *} \\
(0.362)\end{array}$ \\
\hline $\begin{array}{l}\text { Government } \\
\text { Coalition }\end{array}$ & & $\begin{array}{l}-0.714^{* * *} \\
(0.157)\end{array}$ & $\begin{array}{l}-0.750^{* * *} \\
(0.160)\end{array}$ & & \\
\hline $\begin{array}{l}\text { Parties in } \\
\quad \text { Government (ln) }\end{array}$ & & & & $\begin{array}{l}-0.743^{* * *} \\
(0.146)\end{array}$ & \\
\hline $\begin{array}{l}\text { Concentration } \\
\text { Index }\end{array}$ & & & & & $\begin{array}{l}1.565^{* * *} \\
(0.314)\end{array}$ \\
\hline $\begin{array}{l}\text { Proportional } \\
\quad \text { Representation }\end{array}$ & & & $\begin{array}{l}0.473^{* *} \\
(0.186)\end{array}$ & $\begin{array}{l}0.463^{*} \\
(0.187)\end{array}$ & $\begin{array}{l}0.532^{* *} \\
(0.189)\end{array}$ \\
\hline Debt/Output & $\begin{array}{l}0.009^{* *} \\
(0.003)\end{array}$ & $\begin{array}{l}0.010^{* *} \\
(0.004)\end{array}$ & $\begin{array}{l}0.013^{* * *} \\
(0.004)\end{array}$ & $\begin{array}{l}0.013^{* * *} \\
(0.004)\end{array}$ & $\begin{array}{l}0.013^{* * *} \\
(0.004)\end{array}$ \\
\hline $\begin{array}{c}\text { Debt/Service } \\
\text { Payments }\end{array}$ & $\begin{array}{l}0.003^{* * *} \\
(0.001)\end{array}$ & $\begin{array}{l}0.002^{* *} \\
(0.001)\end{array}$ & $\begin{array}{c}0.001 \\
(0.001)\end{array}$ & $\begin{array}{c}0.001 \\
(0.001)\end{array}$ & $\begin{array}{c}0.001 \\
(0.001)\end{array}$ \\
\hline $\begin{array}{l}\text { Current Account/ } \\
\text { GNP }\end{array}$ & $\begin{array}{c}-0.821 \\
(1.450)\end{array}$ & $\begin{array}{r}-1.782 \\
(1.513)\end{array}$ & $\begin{array}{r}-1.598 \\
(1.530)\end{array}$ & $\begin{array}{r}-1.763 \\
(1.531)\end{array}$ & $\begin{array}{r}-1.214 \\
(1.541)\end{array}$ \\
\hline $\begin{array}{l}\text { Reserves/Total } \\
\text { Debt }\end{array}$ & $\begin{array}{c}0.001 \\
(0.001)\end{array}$ & $\begin{array}{r}-0.001 \\
(0.001)\end{array}$ & $\begin{array}{r}-0.001 \\
(0.001)\end{array}$ & $\begin{array}{r}-0.001 \\
(0.001)\end{array}$ & $\begin{array}{r}-0.001 \\
(0.001)\end{array}$ \\
\hline Growth & $\begin{array}{r}-0.692 \\
(0.593)\end{array}$ & $\begin{array}{r}-0.580 \\
(0.630)\end{array}$ & $\begin{array}{r}-0.684 \\
(0.656)\end{array}$ & $\begin{array}{r}-0.630 \\
(0.663)\end{array}$ & $\begin{array}{r}-0.628 \\
(0.650)\end{array}$ \\
\hline $\begin{array}{l}\text { Short-Term/Total } \\
\text { Debt }\end{array}$ & $\begin{array}{r}-0.007 \\
(0.005)\end{array}$ & $\begin{array}{r}-0.010^{*} \\
(0.005)\end{array}$ & $\begin{array}{r}-0.010^{*} \\
(0.005)\end{array}$ & $\begin{array}{r}-0.010^{*} \\
(0.005)\end{array}$ & $\begin{array}{r}-0.008^{*} \\
(0.005)\end{array}$ \\
\hline Past Reschedulings & $\begin{array}{l}0.138^{* * *} \\
(0.015)\end{array}$ & $\begin{array}{l}0.140^{* * *} \\
(0.016)\end{array}$ & $\begin{array}{l}0.133^{* * *} \\
(0.016)\end{array}$ & $\begin{array}{l}0.127^{* * *} \\
(0.015)\end{array}$ & $\begin{array}{l}0.125^{* * *} \\
(0.015)\end{array}$ \\
\hline $\log L 0$ & -326.418 & -326.418 & -326.418 & -324.337 & -319.269 \\
\hline $\log L$ & -198.994 & -188.259 & -184.938 & -181.603 & -181.215 \\
\hline Pseudo- $R^{2}$ & 0.391 & 0.423 & 0.433 & 0.440 & 0.432 \\
\hline$N$ & 502 & 502 & 502 & 500 & 486 \\
\hline
\end{tabular}

Notes: Standard errors are in parentheses.

${ }^{*}$ Significant at a $10 \%$ level, ${ }^{* *}$ significant at a $5 \%$ level, ${ }^{* * *}$ significant at a $1 \%$ level.

respect to the debt-service ratio, the probability of default increases as liquidity problems are more acute. Substantively, this means that at the mean of the covariates, a one-standard-deviation increase in the debt-output ratio raises the probability of debt rescheduling by $26 \%$. Liquidity problems, measured by a one-standard-deviation increase in a country's debt service ratio, raise the probability of default by $15 \%$.

The effect of the current account ratio is statistically indistinguishable from zero. Recall that this variable measures the quantity of investment financed through borrowing from abroad. Therefore, if investment programs involve returns that are inadequate to repay their financing costs, creditors might consider this country to lack the economic control necessary to generate the revenue for debt service (McFadden et al., 1985). Both short-term debt and past defaults have the expected effects. In the case of 
short-term loans, it reflects that a country's behavior is similar to the one displayed by individuals. As their financial conditions deteriorate, countries seek the acquisition of short-term debt to cover liquidity problems. Yet, the marginal effects suggest that at the mean of the covariates, the ability of borrowing short-term funds (a one-standard-deviation increase in shortterm debt) decreases the probability of debt rescheduling by less than $4 \%$. Finally, the variable measuring countries' past behaviors indicates that countries with poor records tend to have higher rescheduling probabilities than those countries with better records. ${ }^{20}$

The results also demonstrate that the more fully specified model including the government type predicts default better than the base model. The probability of a greater $\chi^{2}$ with one degree of freedom is low enough to reject the null hypothesis; therefore, the coalitional nature of the government has a statistically significant effect on default. The model also performs fairly well in predicting debt rescheduling. Taking the mean of the dependent variable $(0.65)$ as the cutoff probability, the model correctly predicts that debt rescheduling will not occur below that threshold in $64 \%$ of the cases. Most importantly, a "false negative" (i.e. the prediction that no default will occur when there is one) only exists for $8.6 \%$ of the cases.

\section{SENSITIVITY AND ROBUSTNESS CHECKS}

This pooled cross-sectional time-series sample inevitably raises concerns regarding time and country effects. In particular, if the observations are temporally dependent, the results of an ordinary probit analysis may be misleading. I estimate a series of additional models to address these concerns.

First, I include a series of dummy variables indicating the number of periods (in years) since the first time an observation enters the dataset in the model specification. This simple solution recognizes that time-series crosssection data with a binary dependent variable are essentially grouped duration data. This formulation is therefore equivalent to an event-history model with discrete time duration data (Beck et al., 1998). In addition, this specification takes into account the possibility of multiple failures (i.e. more than one event of default per country) (Beck et al., 1998). I handle the existence of repeated events with the variable sum of past reschedulings, which is a count of the number of previous events.

To further account for possible problems caused by a temporal correlation of the observations, I also estimate a "transition" model. This model analyzes the transitions from a lagged value of the dependent variable of 0 or 1 to a current value of the dependent variable of 0 or 1 (based on simple firstorder Markov assumptions). This allows for different processes based on the

\footnotetext{
${ }^{20} \mathrm{~A}$ similar finding has been reported by Reinhart et al. (2003). The authors propose the idea of "debt intolerance," and argue that it is linked to the pervasive phenomenon of serial default. Default often exacerbates these problems, making past defaulters more prone to future default.
} 
lagged value of the dependent variable (Amemiya, 1985; Beck et al., 2002). I also address concerns over cross-sectional dependence by estimating a probit model that includes a set of regional dummy variables. This includes Sub-Saharan Africa, South Asia, East Asia, South East Asia, Middle East, Latin America, the Caribbean, Oceania, Europe, and Eastern Europe. ${ }^{21}$

A related issue is case selection. As noted above, the choice of the countries included in this study was dictated by data availability. As a result, the coverage varies across countries. This raises the possibility that the results could be affected by the fact that some countries are sampled more often than others. To address this potential problem, I also conduct the analysis separately for two subsamples of the data: one including those countries with less than 10 observations and another that comprises those countries with 10 or more.

Table 3 presents these alternative specifications. The second column reports the results of the logit model with temporal dummies, while the third column presents the results of the transition model. Column 4 presents the results of the logit model with regional dummies. In the last two columns, the results of the two subsamples [countries with less (more) than 10 observations] are presented. Irrespective of these alternative specifications and sample sizes, the effect of the government type on the probability of default remains robust and statistically significant.

I carry out a few more checks to assess the sensitivity of the results. First, I look at the role of external debt. Developing countries rely on domestic debt to a lesser extent than developed countries and borrow mostly abroad. This raises the issue of the differential ability of domestic and foreign residents to "punish" a government that takes actions detrimental to the value of their holdings. I use data from Cowan, Levy-Yeyati, Panizza, and Sturzenegger (henceforth CLYPS, 2006) to explore the role of external debt. The CLYPS database comprises all countries in the Americas and three non-American economies (New Zealand, Pakistan, and South Africa). The dataset aims at covering the 1980-2004 period but has missing information for some countries in the 1980 s and early 1990 s. $^{22}$

Debt is classified according to the legal jurisdiction where debt has been issued. Accordingly, CLYPS define external liabilities as obligations issued under international (as opposed to domestic) law. Therefore, external debt comprises all liabilities issued in foreign jurisdictions, while domestic debts denote debt under the rule of domestic courts (CLYPS, 2006). Conceptually, the distinction should focus on the residence of the creditor (i.e. external debt is owed to non-residents). However, as CLYPS (2006) note, “... the distinction between debt held by residents and nonresidents is in practice

\footnotetext{
${ }^{21}$ I also estimated a random-effects probit model and obtained very similar results.

${ }^{22}$ Unfortunately there are very few other systematic sources on the composition of public debt. There have been some attempts to build comparable cross-country datasets, but some of them are not publicly available and all of them have a limited country and time coverage.
} 
Table 3 Fixed Effects, “Transition”, and Split-Sample Estimates

\begin{tabular}{|c|c|c|c|c|c|}
\hline & $\begin{array}{c}\text { Logit } \\
\text { dummy }\end{array}$ & Transition $^{b}$ & $\begin{array}{c}\text { Regional } \\
\mathrm{FE}^{c}\end{array}$ & $\begin{array}{l}\text { Less } \\
\text { than } 10\end{array}$ & $\begin{array}{l}10 \text { or } \\
\text { more }\end{array}$ \\
\hline Constant & $\begin{array}{c}-2.481 \\
(1.914)\end{array}$ & $\begin{array}{r}-0.356 \\
(0.522)\end{array}$ & $\begin{array}{r}-1.678^{*} \\
(0.916)\end{array}$ & $\begin{array}{r}-2.303^{*} \\
(1.246)\end{array}$ & $\begin{array}{c}-0.833^{* * *} \\
(0.319)\end{array}$ \\
\hline Government Coalition & $\begin{array}{l}-1.411^{* * * *} \\
(0.305)\end{array}$ & $\begin{array}{c}-0.667^{* *} \\
(0.332)\end{array}$ & $\begin{array}{c}-0.532^{* *} \\
(0.222)\end{array}$ & $\begin{array}{r}-1.100^{*} \\
(0.583)\end{array}$ & $\begin{array}{c}-0.878^{* * *} \\
(0.187)\end{array}$ \\
\hline $\begin{array}{l}\text { Proportional } \\
\quad \text { Representation }\end{array}$ & $\begin{array}{l}0.758^{* *} \\
(0.352)\end{array}$ & $\begin{array}{c}0.605^{*} \\
(0.354)\end{array}$ & $\begin{array}{c}0.236 \\
(0.268)\end{array}$ & $\begin{array}{c}-2.180^{* * * *} \\
(0.749)\end{array}$ & $\begin{array}{l}0.840^{* * * *} \\
(0.225)\end{array}$ \\
\hline Debt/Output & $\begin{array}{l}0.024^{* *} \\
(0.008)\end{array}$ & $\begin{array}{c}0.009 \\
(0.009)\end{array}$ & $\begin{array}{l}0.016^{* *} \\
(0.006)\end{array}$ & $\begin{array}{l}0.038^{* *} \\
(0.016)\end{array}$ & $\begin{array}{l}0.013^{* *} \\
(0.005)\end{array}$ \\
\hline Debt/Service Payments & $\begin{array}{c}0.002 \\
(0.002)\end{array}$ & $\begin{array}{c}-0.005^{* *} \\
(0.002)\end{array}$ & $\begin{array}{l}0.003^{* *} \\
(0.001)\end{array}$ & $\begin{array}{c}0.004 \\
(0.003)\end{array}$ & $\begin{array}{c}0.001 \\
(0.001)\end{array}$ \\
\hline Current Account/GNP & $\begin{array}{r}-1.236 \\
(2.957)\end{array}$ & $\begin{array}{r}-4.338 \\
(2.692)\end{array}$ & $\begin{array}{r}-2.158 \\
(1.860)\end{array}$ & $\begin{array}{c}5.015 \\
(4.524)\end{array}$ & $\begin{array}{r}-2.385 \\
(1.767)\end{array}$ \\
\hline Reserves/Total Debt & $\begin{array}{r}-0.001 \\
(0.001)\end{array}$ & $\begin{array}{r}-0.001 \\
(0.001)\end{array}$ & $\begin{array}{r}-0.001 \\
(0.001)\end{array}$ & $\begin{array}{l}0.019^{*} \\
(0.009)\end{array}$ & $\begin{array}{r}-0.001 \\
(0.001)\end{array}$ \\
\hline Growth & $\begin{array}{r}-1.727 \\
(1.268)\end{array}$ & $\begin{array}{l}1.191 \\
(1.354)\end{array}$ & $\begin{array}{r}-0.403 \\
(0.780)\end{array}$ & $\begin{array}{r}-2.259 \\
(1.880)\end{array}$ & $\begin{array}{r}-0.895 \\
(0.776)\end{array}$ \\
\hline Short-Term/Total Debt & $\begin{array}{r}-0.010 \\
(0.009)\end{array}$ & $\begin{array}{r}-0.014^{*} \\
(0.008)\end{array}$ & $\begin{array}{c}-0.006 \\
(0.008)\end{array}$ & $\begin{array}{r}-0.008 \\
(0.015)\end{array}$ & $\begin{array}{r}-0.007 \\
(0.005)\end{array}$ \\
\hline Past Reschedulings & $\begin{array}{l}0.284^{* * *} \\
(0.036)\end{array}$ & & $\begin{array}{l}0.121^{* * *} \\
(0.021)\end{array}$ & $\begin{array}{l}0.245^{* * *} \\
(0.066)\end{array}$ & $\begin{array}{l}0.135^{* * *} \\
(0.018)\end{array}$ \\
\hline Default (lagged) & & $\begin{array}{l}1.095 \\
(0.691)\end{array}$ & & & \\
\hline $\log L 0$ & -325.540 & -294.6159 & -304.918 & -66.604 & -256.481 \\
\hline $\log L$ & -175.098 & -122.3442 & -152.476 & -28.905 & -142.871 \\
\hline Pseudo- $R^{2}$ & 0.462 & 0.585 & 0.499 & 0.566 & 0.443 \\
\hline$N$ & 500 & 454 & 482 & 117 & 385 \\
\hline
\end{tabular}

Notes: Standard errors are in parentheses.

${ }^{*}$ Significant at a $10 \%$ level, ${ }^{* *}$ significant at a $5 \%$ level, ${ }^{* * *}$ significant at a $1 \%$ level.

${ }^{a}$ Twenty-five temporal dummy variables in specification not shown; two temporal dummies were dropped from the analysis for estimation purposes.

${ }^{\mathrm{b}}$ In the transition model the independent variables are lagged by one year.

${ }^{\mathrm{c}}$ Eight regional dummy variables in specification not shown; Europe was used as the baseline category; the Oceania dummy was dropped from the analysis.

virtually impossible to make ..." The data provide a clear measure of the investor base of bank loans; however "... the holder composition is by definition impossible to track for bonded debt that is continuously traded in anonymous secondary markets ..." For these reasons, the distinction by holder, "... while theoretically relevant, is practically feasible only for countries where the stock of marketable debt is negligible ..." (CLYPS, 2006).

Given this classification, the "external" debt data may be an imperfect proxy of the actual liabilities held by non-residents (Panizza, 2006). Therefore, in order to fully capture the effect of offshoring/onshoring, I also consider an additional measure of domestic debt: the presence of domestic institutional investors. As CLYPS (2006) note, in many developing coun- 
Table 4 Offeshore/Domestic Debt and “Stringent" Estimates of Default

\begin{tabular}{|c|c|c|c|}
\hline & Offshore/Domestic & Offshore/Domestic & Default \\
\hline Constant & $\begin{array}{r}-0.850 \\
(0.848)\end{array}$ & $\begin{array}{c}-2.065^{*} \\
(0.913)\end{array}$ & $\begin{array}{c}-1.119^{* * *} \\
(0.342)\end{array}$ \\
\hline Government Coalition & $\begin{array}{c}-0.551^{*} \\
(0.293)\end{array}$ & & $\begin{array}{c}-0.297^{*} \\
(0.172)\end{array}$ \\
\hline Concentration Index & & $\begin{array}{c}1.354^{*} \\
(0.772)\end{array}$ & \\
\hline Proportional Representation & $\begin{array}{c}-0.216 \\
(0.562)\end{array}$ & $\begin{array}{c}-0.261 \\
(0.534)\end{array}$ & $\begin{array}{l}0.700^{* * * *} \\
(0.173)\end{array}$ \\
\hline Offshore Debt & $\begin{array}{c}0.781 \\
(1.069)\end{array}$ & $\begin{array}{c}0.473 \\
(1.013)\end{array}$ & \\
\hline Pension Fund Holdings & $\begin{array}{r}-0.002^{*} \\
(0.001)\end{array}$ & $\begin{array}{r}-0.002^{*} \\
(0.001)\end{array}$ & \\
\hline Debt/Output & $\begin{array}{c}0.023 \\
(0.018)\end{array}$ & $\begin{array}{c}0.021 \\
(0.018)\end{array}$ & $\begin{array}{l}0.011^{* * * *} \\
(0.003)\end{array}$ \\
\hline Debt/Service Payments & $\begin{array}{c}0.002 \\
(0.002)\end{array}$ & $\begin{array}{c}0.002 \\
(0.002)\end{array}$ & $\begin{array}{c}0.001 \\
(0.001)\end{array}$ \\
\hline Current Account/GNP & $\begin{array}{r}-3.141^{*} \\
(1.808)\end{array}$ & $\begin{array}{r}-3.680^{*} \\
(1.770)\end{array}$ & $\begin{array}{l}4.111^{* *} \\
(1.724)\end{array}$ \\
\hline Reserves/Total Debt & $\begin{array}{c}-0.001 \\
(0.002)\end{array}$ & $\begin{array}{c}-0.001 \\
(0.002)\end{array}$ & $\begin{array}{c}-0.028^{* * *} \\
(0.008)\end{array}$ \\
\hline Growth & $\begin{array}{r}-0.343 \\
(0.847)\end{array}$ & $\begin{array}{r}-0.308 \\
(0.786)\end{array}$ & $\begin{array}{c}0.274 \\
(0.459)\end{array}$ \\
\hline Short-Term/Total Debt & $\begin{array}{c}0.002 \\
(0.021)\end{array}$ & $\begin{array}{c}0.003 \\
(0.020)\end{array}$ & $\begin{array}{c}-0.028^{* * *} \\
(0.011)\end{array}$ \\
\hline Past Reschedulings & $\begin{array}{c}0.082^{*} \\
(0.036)\end{array}$ & $\begin{array}{c}0.089^{*} \\
(0.035)\end{array}$ & $\begin{array}{l}0.171^{* * * *} \\
(0.023)\end{array}$ \\
\hline $\log L 0$ & -52.558 & -52.476 & -310.290 \\
\hline $\log L$ & -24.781 & -24.455 & -159.370 \\
\hline Pseudo- $R^{2}$ & 0.528 & 0.534 & 0.486 \\
\hline$N$ & 191 & 190 & 502 \\
\hline
\end{tabular}

Notes: Standard errors are in parentheses.

${ }^{*}$ Significant at a $10 \%$ level, ${ }^{* *}$ significant at a $5 \%$ level, ${ }^{* * *}$ significant at a $1 \%$ level.

tries, pension reforms created a captive market for public debt. In most cases, offshore investment by pension funds is severely restricted, while domestic investment is usually limited to a set of low-risk assets (CLYPS, 2006).

With this is in mind, the model presented in Table 4 includes the variable Offshore Debt. This measure is calculated as the ratio of total external debt to total debt. ${ }^{23}$ I also include the variable Pension Fund Holdings to further account for the domestic share of public debt. This variable indicates the

${ }^{23}$ Total external debt is defined as total debt instruments issued under international law plus official debt. It is equal to external market instruments plus foreign bank loans plus official debt. The variable is measured in millions of US dollars. Total debt is defined as total central government gross debt. It is equal to total external debt plus total domestic debt. The variable is measured in millions of US dollars. Source: CLYPS (2006). 
private pension holdings of public debt and is measured in millions of US dollars (CLYPS, 2006).

The second and third columns contain the results obtained from the estimation of these additional models. Broadly speaking, the empirical evidence shows that government coalitions reschedule their debts less often, regardless of the creditors' residence. Both the coefficients of the Government Coalition and the Concentration variables are statistically significant and have the correct signs (negative and positive, respectively). Also notice that the coefficient of pension fund holdings is significantly negative. This suggests that higher levels of domestic debt will be associated with a lower probability of debt rescheduling.

So far, the analysis has focused on debt crises involving both debt restructuring and default. While the former has been the prevalent form of sovereign debt repayment problems, episodes of outright default have become more frequent in recent years. To account for this extreme form of delinquency, I estimate a model where debt rescheduling excludes arrears on either principal or interests. In the last column of Table 4, I report the results of this "stringent" model. Consistent with my previous findings, the probability that a country would repudiate its sovereign debt is lower for multiparty coalitions than for single-party governments. ${ }^{24}$

My final check accounts for the potential confounding effects of other institutional variables omitted from my core specifications. This is to ensure that the main finding is not an artifact of parliamentary democracies having fewer reschedulings (Kohlscheen, 2006; Van Rijckeghem and Weder, 2004). To identify the effects of the parliamentary governments on debt rescheduling, I classify political regimes according to the criteria developed by Cheibub (2006). This classification distinguishes presidential from parliamentary and mixed democracies based on the absence of the vote of confidence, which allows the legislature to remove the government during the legislative term (Cheibub, 2006). ${ }^{25}$ According to this criterion, 16 of the 48 countries in the sample are parliamentary.

Another potential concern relates to governments' ideological makeup (Iversen and Soskice, 2006), where center-left governments may be more predisposed to declare a moratorium on their sovereign debts than are center-right governments. If this is the case, then a government's ideological orientation may have an effect on debt repayment, regardless of its coalition status. Leblang (2003) provides data on the ideological orientation of the

\footnotetext{
${ }^{24}$ Even in the "stringent" specification, where I am looking at a relatively rare event - an outright default - the $t$-statistic of the coefficient for government coalition is 1.726.

${ }^{25}$ What distinguishes parliamentary from mixed systems is that the government's existence in the latter depends both on the legislature (through the vote of no confidence) and on a directly elected president, who can remove the government unilaterally or by dissolving the legislature (Cheibub, 2006).
} 
government, which is based on Database of Political Institutions (DPI). The variable Right is a binary indicator that takes the value of 1 if the government comprises right-wing parties, and 0 otherwise (Leblang, 2003).

Table 5 reports the results of the probit models that control for the regime type and government's ideological orientation variables in addition to my core specifications. In columns 4-5, I report the results obtained when the variable measuring the ideological orientation of the government is included in the estimation.

Table 5 Robustness Checks: Role of Regime Type and Ideology

\begin{tabular}{|c|c|c|c|c|}
\hline & Regime $^{\mathrm{a}}$ & Core $^{\mathrm{b}}$ & $\begin{array}{l}\text { Right-wing } \\
\text { Government }\end{array}$ & Augmented \\
\hline Constant & $\begin{array}{r}-0.358 \\
(0.335)\end{array}$ & $\begin{array}{r}-0.162 \\
(0.663)\end{array}$ & $\begin{array}{c}0.038 \\
(0.681)\end{array}$ & $\begin{array}{r}-0.481 \\
(0.857)\end{array}$ \\
\hline Government Coalition & $\begin{array}{c}-0.719^{* * *} \\
(0.162)\end{array}$ & $\begin{array}{c}-1.129^{* * *} \\
(0.292)\end{array}$ & $\begin{array}{c}-1.223^{* * *} \\
(0.306)\end{array}$ & $\begin{array}{c}-1.319^{* * *} \\
(0.328)\end{array}$ \\
\hline Proportional Representation & $\begin{array}{l}0.344^{*} \\
(0.203)\end{array}$ & $\begin{array}{c}0.339 \\
(0.349)\end{array}$ & $\begin{array}{c}0.675 \\
(0.419)\end{array}$ & $\begin{array}{l}0.882^{* *} \\
(0.447)\end{array}$ \\
\hline Parliamentarism & $\begin{array}{c}-0.451^{* *} \\
(0.191)\end{array}$ & & & $\begin{array}{c}0.331 \\
(0.395)\end{array}$ \\
\hline Mixed & $\begin{array}{c}0.091 \\
(0.342)\end{array}$ & & & $\begin{array}{l}1.684^{* *} \\
(0.777)\end{array}$ \\
\hline Right-Wing Government & & & $\begin{array}{r}-0.506^{*} \\
(0.306)\end{array}$ & $\begin{array}{c}-0.413 \\
(0.311)\end{array}$ \\
\hline Debt/Output & $\begin{array}{l}0.013^{* * *} \\
(0.004)\end{array}$ & $\begin{array}{l}0.014^{*} \\
(0.007)\end{array}$ & $\begin{array}{l}0.015^{* *} \\
(0.007)\end{array}$ & $\begin{array}{l}0.016^{* *} \\
(0.007)\end{array}$ \\
\hline Debt/Service Payments & $\begin{array}{c}0.001 \\
(0.001)\end{array}$ & $\begin{array}{c}-0.001 \\
(0.001)\end{array}$ & $\begin{array}{r}-0.001 \\
(0.001)\end{array}$ & $\begin{array}{c}-0.001 \\
(0.001)\end{array}$ \\
\hline Current Account/GNP & $\begin{array}{r}-1.486 \\
(1.547)\end{array}$ & $\begin{array}{c}-0.798 \\
(2.996)\end{array}$ & $\begin{array}{c}-2.409 \\
(3.211)\end{array}$ & $\begin{array}{c}-2.214 \\
(3.367)\end{array}$ \\
\hline Reserves/Total Debt & $\begin{array}{c}-0.001 \\
(0.001)\end{array}$ & $\begin{array}{c}-0.001 \\
(0.007)\end{array}$ & $\begin{array}{r}-0.002 \\
(0.007)\end{array}$ & $\begin{array}{c}-0.002 \\
(0.007)\end{array}$ \\
\hline Growth & $\begin{array}{c}-0.918 \\
(0.674)\end{array}$ & $\begin{array}{c}0.457 \\
(1.342)\end{array}$ & $\begin{array}{c}0.566 \\
(1.347)\end{array}$ & $\begin{array}{c}0.557 \\
(1.501)\end{array}$ \\
\hline Short-Term/Total Debt & $\begin{array}{c}-0.011^{* *} \\
(0.005)\end{array}$ & $\begin{array}{c}-0.031^{* * *} \\
(0.011)\end{array}$ & $\begin{array}{c}-0.031^{* *} \\
(0.012)\end{array}$ & $\begin{array}{r}-0.024^{*} \\
(0.013)\end{array}$ \\
\hline Past Reschedulings & $0.123^{* * *}$ & $0.144^{* * *}$ & $0.138^{* * *}$ & $0.145^{* * *}$ \\
\hline & $(0.016)$ & $(0.021)$ & $(0.021)$ & $(0.025)$ \\
\hline $\log L 0$ & -326.418 & -146.576 & -146.576 & -146.576 \\
\hline $\log L$ & -181.202 & -71.864 & -70.486 & -67.259 \\
\hline Pseudo- $R^{2}$ & .445 & .509 & .519 & .541 \\
\hline$N$ & 502 & 245 & 245 & 245 \\
\hline
\end{tabular}

Notes: Standard errors are in parentheses.

${ }^{*}$ Significant at a $10 \%$ level, ${ }^{* *}$ significant at a $5 \%$ level, ${ }^{* * *}$ significant at a $1 \%$ level.

${ }^{a}$ The excluded category is presidentialism.

${ }^{\mathrm{b}}$ This is like my specification (Table 2), but using the reduced sample. 
Once again, the effect of coalition governments is robust even with the inclusion of the regime type. Parliamentarism has a negative effect on sovereign debt default relative to presidentialism (the excluded category). But regardless of the confidence vote requirement, the effects of coalition remain strong both in statistical and substantive terms. These results should not be surprising. As Cheibub (2006) notes, parties are usually concerned with both cabinet positions and policies. Therefore, coalition partners can also make credible threats under presidentialism because they can withdraw support for policies that the government wishes to pass (Cheibub, 2006). ${ }^{26}$

Unfortunately, due to data restrictions, including the ideology variable reduces the sample size considerably. To ensure that the effect of this variable is not attributed to changes in the sample size, I report the results of my core specification using this reduced sample in column 3. In the next column, I present the results of the model including the government's ideological orientation. The findings corroborate the robustness of the effect of multiparty coalitions after controlling for governments' ideological orientations. ${ }^{27}$ Finally, column 5 of Table 5 presents a model in which both the form of government and the government's ideological orientation are included. Once again, the results demonstrate that multiparty coalitions are less likely to reschedule their debts irrespective of the vote of confidence requirement and the government's ideological makeup. In fact, unlike the coefficient of government coalitions, when both variables are included in the analysis, their respective effects become statistically indistinguishable from zero.

\section{CONCLUDING REMARKS}

This research validates and supports the view that policies and institutions matter for debt sustainability. It also squares well with the notion that relationships between creditor and debtor countries are largely driven by domestic rather than international politics. I find that multiparty coalition governments provide a vehicle to represent the view of those individuals with a stake in debt repayment. My empirical analysis also demonstrates that the effect of multiparty coalitions is quite significant. Having a multiparty coalition government diminishes the probability of debt rescheduling by $19 \%$. To place this percentage in context, recall that a typical increase

\footnotetext{
${ }^{26}$ To further test the possibility that the effect of coalition governments on default may depend on having a vote of confidence procedure, I estimated an alternative model to the one presented in column 2 including an interaction term between parliamentarism and the government's coalition status. The results remain unchanged. Moreover, the interaction effects are for the most part statistically insignificant.

${ }^{27}$ To check if the effect of coalitions depends on having a right-wing government, I estimated an alternative model including an interaction term between the government's ideological orientation and its coalition status. The results remain unchanged, and the interaction effects are for the most part statistically insignificant.
} 
in a country's debt-output ratio would raise the probability of default by $26 \%$.

More broadly, my findings pose important implications for the lending strategies of official creditors such as the World Bank and the IMF. As Kraay and Nehru (2006) note, these organizations tend to focus exclusively on economic indicators to evaluate a country's debt sustainability. The results in this paper suggest that when government debt is owned by a minority of the population - as in most LDCs - and there is a generalized perception that public funds are directed to high-debt service rather than to needed public services, political parties have strong incentives to repudiate the sovereign debt. Therefore, the evaluation of a country's debt sustainability would be incomplete without accounting for the relationship between the government's partisan composition and the politics of debt repayment.

APPENDIX A. LIST OF COUNTRIES IN SAMPLE

\begin{tabular}{|c|c|c|}
\hline Country & Total years & Debt reschedulings \\
\hline Argentina & 15 & 14 \\
\hline Bangladesh & 7 & 7 \\
\hline Barbados & 16 & 14 \\
\hline Benin & 4 & 4 \\
\hline Bolivia & 13 & 13 \\
\hline Brazil & 14 & 14 \\
\hline Bulgaria & 7 & 7 \\
\hline Central African Republic & 2 & 2 \\
\hline Chile & 5 & 1 \\
\hline Colombia & 27 & 18 \\
\hline Comoros & 3 & 3 \\
\hline Costa Rica & 19 & 18 \\
\hline Czech Republic & 2 & 2 \\
\hline Dominican Republic & 24 & 24 \\
\hline Ecuador & 17 & 16 \\
\hline El Salvador & 13 & 13 \\
\hline Ghana & 2 & 2 \\
\hline Guatemala & 10 & 5 \\
\hline Haiti & 2 & 2 \\
\hline Honduras & 13 & 13 \\
\hline Hungary & 8 & 1 \\
\hline India & 23 & 2 \\
\hline Jamaica & 12 & 10 \\
\hline Latvia & 5 & 1 \\
\hline Malawi & 1 & 1 \\
\hline Mali & 6 & 6 \\
\hline Malta & 26 & 5 \\
\hline Mauritius & 21 & 14 \\
\hline Mongolia & 2 & 2 \\
\hline
\end{tabular}


APPENDIX A. Continued

\begin{tabular}{lcc}
\hline Country & Total years & Debt reschedulings \\
\hline Nepal & 7 & 7 \\
Nicaragua & 7 & 7 \\
Niger & 3 & 3 \\
Nigeria & 4 & 3 \\
Papua New Guinea & 20 & 0 \\
Peru & 6 & 6 \\
Philippines & 10 & 6 \\
Poland & 7 & 7 \\
Romania & 8 & 0 \\
Slovak Republic & 4 & 2 \\
South Africa & 3 & 0 \\
South Korea & 10 & 0 \\
Sri Lanka & 9 & 9 \\
Thailand & 15 & 0 \\
Trinidad and Tobago & 19 & 13 \\
Turkey & 21 & 6 \\
Uruguay & 2 & 1 \\
Venezuela & 27 & 1 \\
Zambia & 1 & 324 \\
Total & 502 & \\
\hline
\end{tabular}

\section{ACKNOWLEDGMENTS}

An earlier version of this paper was presented at the Annual Meeting of the Latin American and Caribbean Economic Association, Paris, France, October 2005, and at the Annual Meeting of the American Political Science Association, Boston, August 2008. Albert Fishlow, Eduardo Levy Yeyati, John Londregan, Carmen Reinhart, and participants in the conference on the political economy of recurrent debt (Princeton University), and the Leitner Workshop in International Political Economy (Yale University) provided helpful comments. I am also grateful to Marisa Abrajano, Stephen B. Kaplan, Peter Rosendorff, and three anonymous reviewers for their suggestions. As usual, all errors are solely the author's own.

SEBASTIAN M. SAIEGH

University of California San Diego

\section{REFERENCES}

Amemiya, T., 1985, Advanced Econometrics (Harvard University Press, Cambridge, MA).

Amorim Neto, O., 2000, Presidential cabinets, electoral cycles, and coalition discipline in Brazil, in: S. Morgenstern and B. Nacif, eds., Legislative Politics in Latin America (Cambridge University Press, Cambridge, UK) 48-78. 
Austen-Smith, D., 2000, Redistributing income under proportional representation. Journal of Political Economy 108, 1235-1269.

Bawn, K. and F. Rosenbluth, 2006, Short versus long coalition. American Journal of Political Science 50, 251-265.

Beck, N., D. Epstein, S. Jackman, and S. O'Halloran, 2002, Alternative Models of Dynamics in Binary Time-Series Cross-Section Models (Politics Department, New York University, New York).

- , J. Katz, and R. Tucker, 1998, Taking time seriously. American Journal of Political Science 42, 1260-1288.

Beers, D. T. and J. Chambers, 2006, Sovereign defaults a 26-year low, to show little change in 2007. Standard \& Poor's commentary, September 18.

Bulow, J. and K. Rogoff, 1989, A constant recontracting model of sovereign debt. Journal of Political Economy 97, 155-178.

Cheibub, J. A., 2006, Presidentialism, electoral identifiability, and budget balances in democratic systems. American Political Science Review 100, 353-368.

- - A. Przeworski, and S. Saiegh, 2004, Government coalitions and legislative success under presidentialism and parliamentarism. British Journal of Political Science 34, 565-587.

Cohen, D. and J. Sachs, 1986, Growth and external debt under risk of debt repudiation. European Economic Review 30, 529-560.

Cowan, K., E. Levy-Yeyati, U. Panizza, and F. Sturzenegger, 2006, Sovereign debt in the Americas: new data and stylized facts. Working Paper No.4480, InterAmerican Development Bank, Washington, DC.

Detragiache, E. and A. Spilimbergo, 2001, Crisis and liquidity: evidence and interpretation. IMF Working Paper No.01/2, IMF, Washington, DC.

Dixit, A. and J. Londregan, 1998, Political power and the credibility of government debt. Journal of Economic Theory 94, 80-105.

Eaton, J. and R. Fernandez, 1995, Sovereign Debt (National Bureau of Economic Research, Cambridge, MA).

Edwards, S., 1984, LDC foreign borrowing and default risk. American Economic Review 74, 726-734.

Feder, G. and R. E. Just, 1977, A study of debt servicing capacity applying logit analysis. Journal of Development Economics 4, 25-38.

Gersovitz, M., 1985, Banks' international lending decisions: what we know and implications for future research, in: G. Smith and J. Cuddington, eds., International Debt and the Developing Countries (World Bank, Washington, DC) 61-78.

Golder, M., 2005, Democratic electoral systems around the world, 1946-2000. Electoral Studies 24, 103-121.

Henisz, W., 2000, The institutional environment for economic growth. Economics and Politics 12, 1-31.

Inter-American Development Bank, 2007, Living with Debt: How to Limit the Risks of Sovereign Finance (IADB, Washington, DC).

Iversen, T. and D. Soskice, 2006, Electoral institutions and the politics of coalitions. American Political Science Review 100, 165-181.

Jeanne, O., 2004, Debt maturity and the international financial architecture. IMF Working Paper No. 04/137, IMF, Washington, DC.

Kohlscheen, E., 2006, Sovereign risk: constitutions rule. Mimeo, Department of Economics, University of Warwick, UK.

Kraay, A. and V. Nehru, 2006, When is external debt sustainable? World Bank Economic Review 20, 341-365. 
Laakso, M. and R. Taagepera, 1979, "Effective" number of parties. A measure with application to West Europe. Comparative Political Studies 12, 3-27.

Leblang, D., 2003, To devalue or to defend? The political economy of exchange rate policy. International Studies Quarterly 47, 533-559.

Lizzeri, A. and N. Persico, 2001, The provision of public goods under alternative electoral incentives. American Economic Review 91, 225-239.

McFadden, D., R. Eckaus, G. Feder, V. Hajivassiliou, and S. O'Cormell, 1985, Is there life after debt?, in: G.W. Smith and J.T. Cuddington, eds., International Debt and the Developing Countries (IBRD, Washington, DC) pp. 179-209.

Min, H.-G., D.-H. Lee, C. Nam, M.-C. Park, and S.-H. Nam, 2003, Determinants of emerging-market bond spreads: cross-country evidence. Global Finance Journal 14, 271-286.

Myerson, R. B., 1993, Incentives to cultivate favored minorities under alternative electoral systems. American Political Science Review 87, 856-869.

Palac-McMilken, E. D., 1995, Rescheduling, Creditworthiness and Market Prices (Avebury, Aldershot, UK).

Panizza, U., 2006, Domestic and external public debt in developing countries. Mimeo, UNCTAD.

Persson, T., G. Roland, and G. Tabellini, 2003, How do electoral rules shape party structures, government coalitions, and economic policies? NBER Working Paper No. 10176, National Bureau of Economic Research.

Pinto, P. M., 2005, Does partisanship affect the regulation of foreign investment? Mimeo, Department of Political Science, Columbia University.

Reinhart, C. M., K. S. Rogoff, and M. A. Savastano, 2003, Debt intolerance. Brookings Papers on Economic Activity 1, 32-74.

Rodrik, D. and A. Velasco, 1999, Short-term capital flows. Paper presented at the 1999 World Bank ABCDE Conference.

Roubini, N. and P. Manasse, 2005, "Rules of thumb" for sovereign debt crises. IMF Working Paper No. 05/42.

Sachs, J., 1981, The current account and macroeconomic adjustment in the 1970s. Brookings Papers on Economic Activities 1, 201-268.

- 1984 , Theoretical issues in international borrowing. Princeton Studies in International Finance 54.

— and D. Cohen, 1982, LDC borrowing with default risk. NBER Working Paper No. 925.

- 2003, Public Debt and the Birth of the Democratic State (Cambridge University Press, New York).

Theil, H., 1972, Statistical Decomposition Analysis (North-Holland, Amsterdam).

Tomz, M., 2002, Democratic default: domestic audiences and compliance with international agreements. Mimeo, Department of Political Science, Stanford University.

—_ 2003, Domestic attitudes toward debt repayment. Mimeo, Department of Political Science, Stanford University.

- and M. L. J. Wright, 2007, Do countries default in bad times? Journal of the European Economic Association 5, 352-360.

Tsebelis, G., 2002, Veto Players: How Political Institutions Work (Princeton University Press, Princeton, NJ).

Van Rijckeghem, C. and B. Weder, 2004, The Politics of Debt Crises (Centre for Economic Policy Research, London).

World Bank, 1999, Global Development Finance 1999 (World Bank, Washington, DC). 1999, World Development Report 1999/2000: Entering the 21st Century (World Bank, Washington, DC). 